\title{
Some quantitative aspects of protein and carbohydrate absorption in the pig*
}

By A. A. ReRAT, Laboratoire de Physiologie de la Nutrition I.N.R.A. - C.N.R.Z. - 78350 Fouy-en-Fosas, France

A great number of studies have been made the last few years in the fields of gastrointestinal physiology, biochemistry and pathology in the pig. Scientists consider the pig as a valuable animal not only in terms of production, but also as a model resembling the human species more than the rodent does, its feeding behaviour being quite similar (mainly diurnal feeding pattern: Auffray et al. 1974) as well as the anatomy of its gastrointestinal system. Owing to several methods developed in the last 20 years, large samplings can be made in vivo in the pig from the whole intestine or segments of the latter allowing a quantification of a certain number of measures. It is thus possible to examine the variation in the digestive contents according to time and space, to distinguish between digesta of exogenous or endogenous origin, to measure their disappearance in the various segments of the digestive tract and their appearance in the body fluids. Several recent reviews dealing with the pig concern either the digestion in general (Kidder \& Manners, 1978), or specific problems such as in vivo methodology (Laplace, 1972; Low, 1977, I980; Rerat et al. 1980) or in vitro methodology (Smith, 1980), proteins (Rerat, 1972; Rerat et al. 1976; Zebrowska, 1980), carbohydrates and lipids (Sambrook, 1980), minerals (Partridge, 1980), secretions (Corring, 1979, 1980), motricity and transit (Laplace, 1979, 1980).

The present paper presents some new results on the appearance of protein and carbohydrate nutrients in the body fluids. First, however, a description will be made of the technology used for measuring those nutrients.

\section{Methods for measuring the appearance of nutrients in the body fluids}

Increase in the amount of the nutrient studied is measured in the portal vein, the thoracic duct or some of their collaterals. Variations in the concentration of nutrients at that level reflect the digestive processes of the feeds (transit, mixture with secretions and desquamations, changes caused by enzymes and microflora) and the possible metabolization in the gut wall. The lymph has been little studied and principally with respect to absorption of lipids (Raulin et al. 1966) but also in connection with absorption of protein hydrolysis products (Aliev \& Ataev, 1972; Aliev et al. 1978). The most studied pathway is that of the blood in particular in the case of absorption of protein hydrolysis products (Rerat et al. 1976). A qualitative description of the absorption can be made from the porto-arterial

-The full text of the report presented at the Nutrition Society Symposium (7.12.79) will be published in World Review of Nutrition and Dietetics (1980). 
differences in the nutrient concentration indicating the degree of enrichment of the portal blood draining the whole gut, relative to the afferent arterial blood of the intestine. A quantitative description of the absorption can be made by measuring simultaneously the blood flow rate in the portal vein. Blood samples can be obtained by permanent catheterizations of the portal vein (Arsac \& Rerat, 1962) and the carotid artery (Rerat, 1977). The portal blood flow rate can be measured by means of various techniques, the most currently used in the pig being the electromagnetic flowmeter. The absorption is calculated by combining these two techniques according to the formula: $Q=(C p-C a) D d t$, where $(C p-C a)$ represents the porto-arterial differences in the nutrient concentration, $D$ the blood flow rate in the portal vein, and $Q$ the amount absorbed within the time interval $d t$ (Rerat et al. 1980).

This measure concerns only the apparent absorption; indeed, some nutrients coming from the intestinal lumen or the arterial blood may be metabolized or catabolized in the intestinal wall. For a given nutrient ingested the absorption balance obtained corresponds to the excess of absorption relative to the metabolization in the gut wall when the porto-arterial difference is positive or to the excess of the metabolization in the gut wall relative to the absorption, when this difference is negative. For a non-ingested nutrient, this method allows to measure its apparent synthesis by the cell wall.

\section{Appearance of nutrients in the body fluids during digestion of carbohydrates and proteins}

The transport and absorption of various nutrients have been investigated, especially in the last ro years, in a great number of species other than the pig. An attempt was generally made in these experiments to describe the hydrolysis and transport processes without, however, the possibility of quantifying them by means of techniques allowing the determination of disappearance of nutrients in vitro (Smith, I980), or in vivo (Silk, 1977). The advances made in these fields are very important and concern in particular the transport mechanisms of oligopeptides and amino acids (Matthews, 1972, 1977; Munck, 1976) as well as those of simple carbohydrates (Crane, 1968; Gray, 1970, 1975). In the pig, very few studies were made with in vitro techniques although the transport mechanisms do not always seem to be the same as in the other species (Daniels, 1972). Opposite to that some in vivo studies were made on the postprandial appearance of nutrients in the body fluids (blood or lymph) draining the digestive tract. It will thus be possible to understand the factors responsible for the metabolism of nutrients and to determine whether the synchronized supply of nutrients in the tissues play effectively the role defined by Geiger (1950) for amino acids or by Cuthbertson \& Munro (1939) for energy and protein.

\section{Absorption kinetics and balance of carbohydrates of various dietary origins}

Qualitative aspects. The peripheral glycemia increases as the carbohydrates disappear from the intestinal lumen. This rise is variable according to the 
Table I. Variations in the amounts of reducing sugars appearing in the pig during a postprandial period of $8 h^{*}$

(Mean values with their standard deviations; no. of pigs in parentheses)

\begin{tabular}{|c|c|c|c|c|c|c|c|c|}
\hline \multirow[b]{3}{*}{ Food intake: } & \multicolumn{8}{|c|}{ Period after meal (h) } \\
\hline & \multicolumn{2}{|c|}{2} & \multicolumn{2}{|c|}{4} & \multicolumn{2}{|c|}{6} & \multicolumn{2}{|c|}{8} \\
\hline & Mean & SD & Mean & SD & Mean & SD & Mean & SD \\
\hline \multicolumn{9}{|l|}{$400 \mathrm{~g}$} \\
\hline Cerelose (6) & 77 & 10 & 177 & 30 & 228 & 43 & $24 I$ & $4^{\circ}$ \\
\hline Sucrose (10) & 84 & II & 175 & 25 & 229 & 34 & 257 & 40 \\
\hline Lactose (5) & 40 & 3 & 79 & 7 & 103 & 7 & 119 & 9 \\
\hline Maize starch (7) & 69 & 9 & $\mathbf{I}^{1} \mathrm{I}$ & 25 & 176 & 29 & $2 I_{4}$ & 30 \\
\hline \multicolumn{9}{|l|}{$800 \mathrm{~g}$} \\
\hline Cerelose (4) & I 57 & 21 & 345 & 43 & $4^{8} 3$ & 36 & 592 & 27 \\
\hline Sucrose (5) & II 8 & 17 & 287 & 25 & 432 & 24 & 521 & 28 \\
\hline I actose (4) & 32 & 10 & 62 & 20 & 88 & 28 & II3 & 35 \\
\hline Maize starch (5) & 102 & I0 & 220 & 33 & 302 & 49 & 360 & 55 \\
\hline
\end{tabular}

-Rerat (1977) and Rerat et al. (1978).

carbohydrate ingested and changes with the age of the animal which conditions its enzyme capacities (Dollar et al. 1957; Cunningham, 1959; Kidder et al. 1963; Ly \& Velasquez, 1970). Systematic studies made in 3-month-old animals (Aumaitre et al. 1973, 1975; Rerat et al. 1977) show that the portal blood level of reducing sugars increases rapidly. The magnitude of the level reached as well as the time elapsed to reach it and to decrease are highly variable from one carbohydrate to another. The arterial glycemia follows the portal fluctuations and sometimes increases in large proportions. Thus, according to the sugar ingested the liver is more or less able to retain the flux of nutrients reaching this organ. The portoarterial differences are highly marked for glucose and sucrose; less marked but persistent for maize starch and very small for lactose.

Quantitative aspects-absorption balance of reducing sugars during a postprandial period of $8 \mathrm{~h}$. The amounts of reducing sugars appearing in the body during a postprandial period of $8 \mathrm{~h}$ vary according to the sugar ingested (Rerat et al. 1974; Rerat et al. 1977). Except for lactose, they increase simultaneously with the ingestion level, but the over-all pattern is different for each sugar according to the amounts ingested (see Table $\mathrm{I}$ ). Cerelose and sucrose are digested more rapidly than starch. In the case of lactose there is no relationship between the amounts of sugars appearing in the portal vein and the amounts ingested and the rather low absorption coefficient is almost reduced to half when the intake level is doubled. Accordingly, there is a limiting factor probably involving either the hydrolysis of lactose or the absorption of its hydrolysis products. The differences between the various sugars and levels appear very early. A comparison of gastric emptying values for starch (Cuber \& Laplace, $1979 b$ ) and the values concerning the 
portal appearance of reducing sugars after intake of an analogous amount of a semi-synthetic diet based on starch shows that the processes of starch hydrolysis and the absorption of the hydrolysis products do not seem to be able to follow the very rapid gastric emptying of starch which accumulates in the intestine during the first hours after the meal. Thus, the starch digestion rate seems to be limited by the process of degradation and absorption.

In conclusion, large amounts of maize starch and of lactose still subsist in the digestive tract $8 \mathrm{~h}$ after the meal, whereas the digestion of glucose or sucrose is much advanced. This is confirmed by the concordance between the duration of gastric emptying after ingestion of starch (Laplace, 1979) and the persistence of the porto-arterial differences in the concentration of reducing sugars (Rerat, 1977). Consequently, the digestive tract of the pig is able to store large amounts of energy for a long period after ingestion of meals based on maize starch or lactose. Moreover, as these carbohydrates are present in the gut for a long time they may constitute substrates for the microbial proliferation leading to the formation of useful or noxious substances.

\section{Absorption of protein hydrolysis products}

In the pig only few investigations have been made using the lymph to study protein absorption. According to Aliev \& Ataev (1972) and Aliev et al. (1978) the substances absorbed do not only appear in the organism in the form of free amino acids, but also in the form of proteins synthesized in the intestinal cell wall and thereafter conveyed to the portal blood and the lymph.

Concerning the blood route, it is well known that the amino acidemia increases after a protein meal, but more markedly in the portal than in the systemic blood. This increase occurs rapidly and lasts for a long or short time according to the quality and nature of the protein ingested (Rerat et al. 1976).

The last few years, quantitative investigations have been made systematically in the pig. Some information on the comparative absorption rates of proteins, carbohydrates and their hydrolysis products will be given.

Table 2. Relationships between the amounts of amino acids $(\mathrm{Y} / \mathrm{g})$ and reducing sugars absorbed $\left(\mathrm{Y}^{\prime} / g\right)$ and the amounts of crude protein $(\mathrm{X} / \mathrm{g})$ and sugars ingested $\left(\mathrm{X}^{\prime} / g\right)$

\begin{tabular}{|c|c|c|c|c|c|c|c|}
\hline & $\begin{array}{l}\text { Period } \\
\text { after } \\
\text { meal (h) }\end{array}$ & $\boldsymbol{n}$ & Regression equation & $r$ & $X$ & $\boldsymbol{Y}$ & $\begin{array}{l}\text { Statistical } \\
\text { significance } \\
\text { of difference }\end{array}$ \\
\hline $\begin{array}{l}\text { Wheat } \\
\text { Barley }\end{array}$ & $\begin{array}{l}8 \\
8\end{array}$ & $\begin{array}{l}16 \\
12\end{array}$ & $\begin{array}{l}Y=0.459 X+14.244 \\
Y=0.302 X+9.230\end{array}$ & $\begin{array}{l}0.805 \\
0.842\end{array}$ & $\begin{array}{r}117 \cdot 6 \\
74 \cdot 5\end{array}$ & $\begin{array}{l}68 \cdot 2 \\
31 \cdot 2\end{array}$ & $\because$ \\
\hline $\begin{array}{l}\text { Wheat } \\
\text { Barley }\end{array}$ & $\begin{array}{l}8 \\
.8\end{array}$ & $\begin{array}{l}16 \\
16\end{array}$ & $\begin{array}{l}Y^{\prime}=0.366 X^{\prime}+56.925 \\
Y^{\prime}=0.309 X^{\prime}+47.047\end{array}$ & $\begin{array}{l}0.821 \\
0.880\end{array}$ & $\begin{array}{l}626 \cdot 9 \\
475 \cdot 4\end{array}$ & $\begin{array}{l}286 \cdot 4 \\
193 \cdot 9\end{array}$ & $\because$ \\
\hline
\end{tabular}


Comparison between absorption rates of protein and carbohydrate hydrolysis products. Some results referring to the digestion of two cereals, wheat and barley, are given in Table 2 (Rerat, Vaissade et al. 1979). The relationships between amounts absorbed during a postprandial period of $8 \mathrm{~h}$ and the amounts ingested can be described by Ist degree equations (Table 2). Wheat proteins exhibit the highest digestion rate. The slopes of the regression lines at $8 \mathrm{~h}$ are significantly different between wheat and barley proteins, and between protein and reducing sugars of wheat. Conversely, there is no difference either between reducing sugars of the two cereals or between reducing sugars and proteins of barley. This possibility of a differential digestion of proteins and carbohydrates may have important nutritional consequences, especially for the valorization of $\mathrm{N}$ retention by the energy supply.

Composition of the amino acid mixture absorbed after ingestion of various proteins. Using as a basis the amounts of each amino acid absorbed at various time intervals after the meal, it is possible to determine the composition of the amino acid mixture absorbed and to compare it with that of the proteins ingested. This composition may be expressed in the form of patterns of amino acids absorbed, either relative to the sum of essential amino acids or relative to the sum of nonessential amino acids. By comparison with the profile of essential and non-essential amino acids of the proteins ingested (in this case, wheat, barley, fish) it is possible

Table 3. Composition of the essential amino acids absorbed $(\%)$ and difference from composition of amino acids ingested (\%) during a period of $8 \mathrm{~h}$ after the intake of wheat, barley or fish meal

(No. of pigs/diet in parentheses)

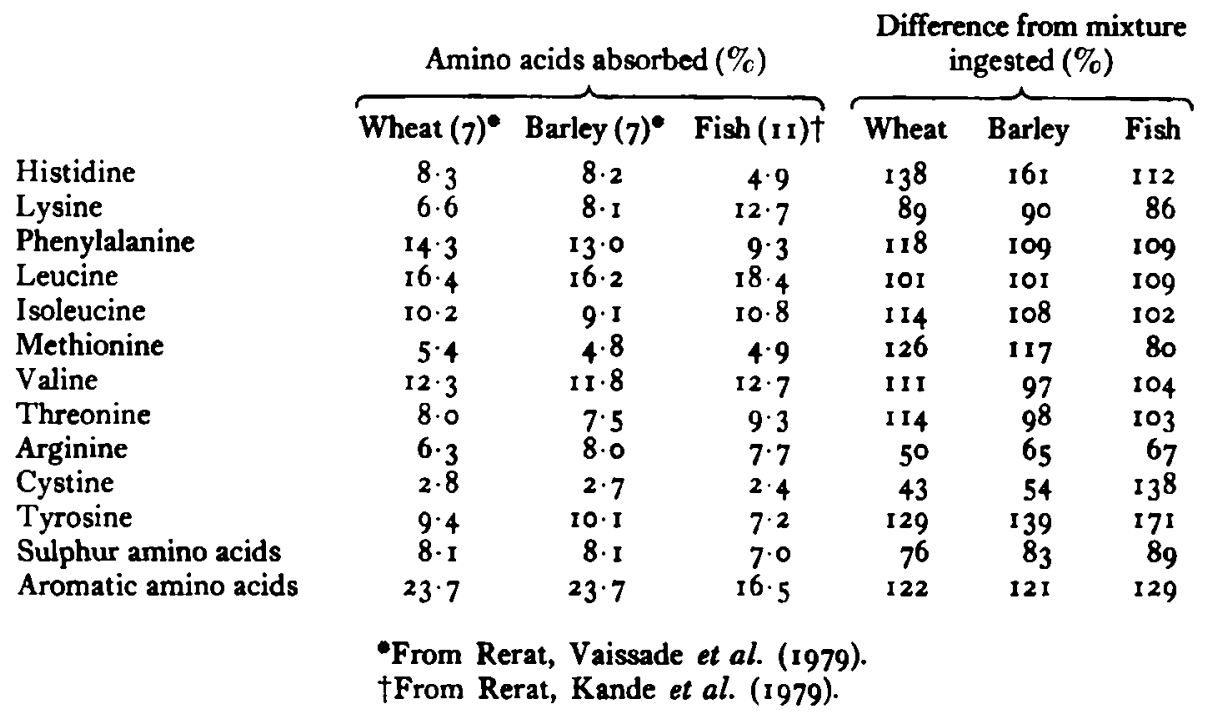


to determine the relative absorption rate of the essential amino acid relative to the mixture of the essential ones and that of the non-essential amino acids relative to the mixture of non-essential ones (Rerat, Vaissade et al. 1979).

In these conditions, the profile of the mixture of amino acids absorbed within $8 \mathrm{~h}$ (Table 3) closely depends on the profile of the essential amino acids ingested without completely resembling it. Thus, whatever the protein ingested, the over-all absorption rate of the ramified amino acids and threonine is close to that of the mixture; the absorption rate of histidine and aromatic amino acids is much faster; contrary to that, the total cumulated absorption of lysine, sulphur amino acids and especially arginine is slower. Although the concentration of lysine is much higher in fish than in cereal proteins and that of aromatic amino acids much lower in fish than in cereal proteins, the behaviour of these amino acids relative to the mixture of essential amino acids is the same for the three proteins (wheat, barley, fish) as if there is an identical chronology in the degradation and absorption of their essential amino acids whatever the concentration of the latter.

The mixture of non-essential amino acids absorbed (Table 4 ) undergoes marked changes in the same direction for the three proteins, but of variable extent according to the protein considered. Thus, a large excess of alanine and glycine is observed particularly in cereals and large aspartic and glutamic acids deficiencies especially in fish. These modifications correspond to the transaminations occurring in the gastrointestinal cell wall as shown previously by Neame \& Wiseman (1958) and Pion et al. (1964).

These results clearly show that although digestion is a more or less rapid and early process according to the protein considered, the sequence of release of the various amino acids does not seem to depend on their relative proportion in the protein.

Table 4. Composition of the mixture of non-essential amino acids absorbed (\%) and difference from composition of amino acids ingested (\%) during a period of $8 \mathrm{~h}$ following the intake of wheat, barley or fish meal

(No. of pigs/diet in parentheses)

\begin{tabular}{|c|c|c|c|c|c|c|}
\hline & \multicolumn{3}{|c|}{$\begin{array}{l}\text { Non-essential amino } \\
\text { acids absorbed (\%) }\end{array}$} & \multicolumn{3}{|c|}{$\begin{array}{c}\text { Difference from } \\
\text { mixture ingested }(\%)\end{array}$} \\
\hline & Wheat $(7)^{\circ}$ & Barley (7) & Fish (I I $) \dagger$ & Wheat & Barley & Fish \\
\hline $\begin{array}{l}\text { Aspartic acid + asparagine } \\
\text { Proline+hydroxyproline }\end{array}$ & $\begin{array}{r}7.3 \\
17.4\end{array}$ & $\begin{array}{l}10 \cdot 1 \\
14 \cdot 1\end{array}$ & $\begin{array}{l}11 \cdot 3 \\
12 \cdot 8\end{array}$ & $\begin{array}{l}80 \cdot 8 \\
88 \cdot 5\end{array}$ & $\begin{array}{l}88 \cdot 6 \\
68 \cdot 4\end{array}$ & $\begin{array}{r}52 \\
122\end{array}$ \\
\hline Serine & 10.1 & $8 \cdot 4$ & $7 \cdot 5$ & 128.8 & I I I I I & 93 \\
\hline Glutamic acid + glutamine & $13 \cdot 7$ & $7 \cdot 2$ & $2 \cdot 3$ & $28 \cdot 2$ & $56 \cdot 2$ & 7 \\
\hline Glycocolle & II. 6 & II 8 & $14 \cdot 2$ & $168 \cdot I$ & 147.9 & 105 \\
\hline Alanine & $26 \cdot 5$ & $31 \cdot 4$ & $3^{6 \cdot 7}$ & $47^{2 \cdot 2}$ & $397 \cdot 8$ & 255 \\
\hline Citrulline & 6.61 & $8 \cdot 33$ & $9 \cdot 6$ & - & - & 一 \\
\hline Ornithine & $3 \cdot 28$ & 3.85 & $3 \cdot 4$ & - & - & 一 \\
\hline
\end{tabular}


Due to lack of space, very important aspects of the digestive processes are not given in this paper and will be discussed elsewhere (Rerat, 1980). This is particularly the case for the gastrointestinal secretions and their regulation, the role of the stomach in digestion, and digestion of proteins and carbohydrates in the different parts of the gut (small intestine, hind-gut) and subsequent disappearance of their hydrolysis products. Results are only given concerning kinetics and balance of appearance in the portal blood of hydrolysis products of some proteins (wheat, barley, fish meal) and carbohydrates (cerelose, sucrose, lactose, maize starch).

A systematic use of this methodology is very promising as it contributes to a better understanding of the results obtained by other techniques aiming at measuring the segmental or total disappearance of the hydrolysis products in the gastrointestinal tract. It may help to estimate the role of the 'time-factor' when the nutrients arrive at the site of protein synthesis.

The author acknowledges Mrs K. Rerat for translating this report into English, and Mrs F. Wehrlen for collecting the bibliographical material.

\section{REFERENCES}

Aliev, A. A. \& Ataev, U. I. (1972). Doklady Vsesoyuznoi Ordena Lenina Akademii Sel'skokhozyaistvennykh Nauk $5,27$.

Aliev, A. A., Ataev, U. I. \& Blinov, V. I. (1978). Vestnik Sel'skokhoryaistvennoi Nauki, Moscow, USSR I, 54 .

Arsac, M. \& Rerat, A. A. (1962). Ann. Biol. anim. Biochem. Biophys. 2, 335.

Auffray, P., Bahy, C. \& Marcilloux, J. C. (1974). Foumées Rech. Porcine en France, Paris 6, 277.

Aumaitre, A., Rerat, A. A., Vaissade, P. \& Vaugelade, P. (1975). Ann. Biol. anim. Biochem. Biophys. 15, 547.

Aumaitre, A., Rerat, A. A., Vaissade, P. \& Vaugelade, P. (1973). Ann. Biol. anim. Biochem. Biophys. 13, 784 .

Buraczewska, L. \& Zebrowska, T. (1972). Zesz. probl. Postęp. Nauk Roln. 126, 129.

Corring, T. (1979). Med. et Nutr. XV, 25.

Corring, T. (1980). In Current concepts of digestion and absorption in pigs. [A. G. Low and I. G. Partridge, editors]. Reading: NIRD.

Crane, R. K. (1968). In Handbook of Physiology, Section 6, Alimentary Canal, Vol. III intestinal absorption. [C. F. Code, editor]. p. 1323 .

Cuber, J. C. \& Laplace, J. P. (1979a). Ann. Zootech. 28, 173.

Cuber, J. C. \& Laplace, J. P. (1979b). Ann. Biol. anim. Biochem. Biophys. 19, 899.

Cunningham, H. M. (1959). F. Anim. Sci. 18, 964.

Cuthbertson, D. P. \& Munro, H. N. (1939). Biochem. F. 33, I 28.

Daniels, V. G. (1972). Comp. Biochem. Physiol. 42A, 689.

Dollar, A. M., Mitchell, H. G. \& Porter, J. W. G. (1957). Proc. Nutr. Soc. 16, xii.

Geiger, E. (1950). Science, N.Y. I11, 594.

Gray, G. M. (1970). Gastroenterology 58, 96.

Gray, G. M. (1975). N. Engl. F. Med. 292, 1225.

Kidder, D. E. \& Manners, M. J. (1978). Digestion in the Pig, p. 201. Bristol: Scientechnica.

Kidder, D. E., Manners, M. J. \& McCrea, M. R. (1963). Res. Vet. Sci. 4, 131.

Laplace, J. P. (1970). Ann. Zootech. 19, 287.

Laplace, J. P. (1972). Ann. Zootech. 21, 83.

Laplace, J. P. (1979). Med. et Nutr. XV, 17.

Laplace, J. P. (1980). In Current concepts of digestion and absorption in pigs. [A. G. Low and I. G. Partridge, editors]. Reading: NIRD.

Low, A. G. (1977). Proc. Nutr. Soc. 36, 189. 
Low, A. G. (1980). In Current concepts of digestion and absorption in pigs. [A. G. Low and I. G. Partridge, editors]. Reading: NIRD.

Ly, J. \& Velasquez, M. (1970). Rev. Cubana Cienc. agric. (Eng. edn.) 4, 195.

Mason, V. C. (1978). 3rd World Conference of Animal Feeding, Madrid, A II 3, 197.

Matthews, D. M. (1972). Proc. Nutr. Soc. 31, 171.

Matthews, D. M. (1977). Gastroenterology 73, 1267.

Munck, B. G. (1976). In Protein Metabolism and Nutrition [D. J. A. Cole, K. N. Boorman, P. J. Buttery, D. Lewis, R. J. Neale and H. Swan, editors]. London, Boston: Butterworths.

Neame, K. D. \& Wiseman, G. (1958). F. Physiol., Lond. 140, 148.

Partridge, I. G. (1980). In Current concepts in digestion and absorption in pigs [A. G. Low and I. G. Partridge, editors]. Reading: NIRD.

Pion, R., Fauconneau, G. \& Rerat, A. A. (1964). Ann. Biol. anim. Biochem. Biophys. 4, 383. Raulin, J., Loriette, C., Flanzy, J. \& Rerat, A. A. (1966). Biochem. biophys. Acta 116, 385.

Rerat, A. A. (1972). Nutr. Abstr. Rev. 42, 13.

Rerat, A. A. (1977). Ier Colloque sur la réanimation entérale à faible débit continu, INSERM Paris, Nov. 1975. 53, 47 .

Rerat, A. A. (1980). Wld Rev. Nutr. Diet. (In the Press).

Rerat, A. A., Aumaitre, A., Vaissade, P. \& Vaugelade, P. (1974). C. R. Acad. Sci. 279D, 83 r.

Rerat, A. A., Aumaitre, A., Vaissade, P. \& Vaugelade, P. (1977). Ann. Biol. anim. Biochem. Biophys. 17, $5^{89}$.

Rerat, A. A., Corring, T. \& Laplace, J. P. (1976). In Protein metabolism and Nutrition p. 97. [D. J. A. Cole, K. N. Boorman, P. J. Buttery, D. Lewis, R. J. Neale and H. Swan, editors]. London, Boston: Butterworths.

Rerat, A. A., Corring, T. \& Laplace, J. P. (1978). fournées Rech. Porcine en France, Paris 10, 99.

Rerat, A. A., Kande, J., Jung, J., Vaissade, P. \& Vaugelade, P. (1979). Fournées 'IngestionDigestion-Absorption' de l'Association Française de Nutrition, Paris 15-16 Novembre 1979.

Rerat, A. A., Vaissade, P. \& Vaugelade, P. (1979). Ann. Biol. anim. Biochem. Biophys. 19, 739.

Rerat, A. A., Vaugelade, P. \& Villiers, P. A. (1980). In Current concepts of digestion and absorption in pigs. [A. G. Low and I. G. Partridge, editors]. Reading: NIRD.

Sambrook, I. E. ( 1980 ). In Current concepts of digestion and absorption in pigs. [A. G. Low and I. G. Partridge, editors]. Reading: NIRD.

Silk, D. B. A. (1977). In Peptide transport and hydrolysis, Ciba foundation Symposium $5^{\circ}$ (new series) p. I5. Amsterdam: Elsevier.

Smith, M. W. (1980). In Current concepts of digestion and absorption in pigs. [A. G. Low and I. G. Partridge, editors]. Reading: NIRD.

Zebrowska, T. (1980). In Current concepts of digestion and absorption in pigs. [A. G. Low and I. G. Partridge, editors]. Reading: NIRD. 